Guide to the Liverworts of North Carolina 



\section{Guide to the Liverworts}

\section{of North Carolina marie L. Hicks}

DUKE UNIVERSITY PRESS Durham and London 1992 
(C) 1992 Duke University Press

All rights reserved

Printed in the United States of America

on acid-free paper $\infty$

Library of Congress Cataloging-in-Publication

Data appear on the last printed page of this book. 